\title{
The influence of kinesiotherapy on joint motion and process of strengthening selected muscules of leg after the episode of knee joint sprain
}

\section{Wpływ kinezyterapii na ruchomość stawowa i wzmacnianie wybranych mięśni kończyny dolnej po epizodzie skręcenia stawu kolanowego}

\author{
Jacek Wilczyński, Adam Bandyra, Katarzyna Szaraniec
}

Department of Neurology, Neurological Rehabilitation and Kinesis, Institute of Physiotherapy, Faculty of Health Sciences, Jan Kochanowski University, Kielce, Poland

Director of the Institute: Prof. UJK Zbigniew Śliwiński MD, PhD

Key words: knee joint sprain, ligament damage, knee instability, physiotherapy, kinesiotherapy.

Słowa kluczowe: skręcenie stawu kolanowego, uszkodzenie więzadeł, niestabilność stawu kolanowego, fizjoterapia, kinezyterapia.

\begin{abstract}
Introduction: Traumatic damage to the knee joint by twisting is a common health problem in people of all ages. Aim of the research: To compare the results of 3-week complex physiotherapy (kinesiotherapy and physiotherapy) with partial physiotherapy (physical therapy) in the process of rehabilitation of the knee joint after twisting.

Material and methods: A factor differentiating groups was medical gymnastics - kinesiotherapy. Fifty patients of the Rehabilitation Unit of the District Hospital in Staszów divided into two numerically equal groups of subjects (25 people each) were assessed twice (before and after improving physiotherapy) for muscle strength and range of movement of the knee joint. Each participant of the rehabilitation had the healthy lower limb compared to the injured one treated with physiotherapy activities in terms of the above-mentioned indicators. The age of patients with damage to the knee joint was between 20 and 64 years old. The median age was 42 years. The patients were from urban and rural areas of the Staszów town region. They represented various professions.

Results: The applied physiotherapy improved muscle strength (measured in Lovett scale points) and increased the range of movements (defined in degrees with a goniometer) of the injured knee. While assessing the effects of the therapy, there was no significant difference between the groups of studied subjects who underwent complex and partial rehabilitation.

Conclusions: The obtained results of rehabilitation showed that the model of physiotherapy enhanced with physical exercise allows for faster muscle growth and increases the amplitude of the range of motion in the injured joint.
\end{abstract}

\section{Streszczenie}

Wstęp: Urazowe uszkodzenie stawu kolanowego w wyniku skręcenia to powszechnie spotykany problem natury zdrowotnej u osób w różnym wieku.

Cel pracy: Porównanie wyników 3-tygodniowej kompleksowej fizjoterapii (kinezyterapia i fizykoterapia) z częściową fizjoterapią (fizykoterapia) w procesie usprawniania stawu kolanowego po przebytym skręceniu.

Materiał i metody: Czynnikiem różnicującym grupy była gimnastyka lecznicza - kinezyterapia. U 50 pacjentów z Oddziału Rehabilitacji Dziennej Szpitala Powiatowego w Staszowie podzielonych na dwie równe liczebnie grupy badanych (po 25 osób) dwukrotnie oceniano (przed usprawnianiem fizjoterapeutycznym i po) siłę mięśniową i zakresy ruchów w stawie kolanowym. Według wyżej wymienionych wyznaczników u każdego uczestnika rehabilitacji porównano także kończynę dolną zdrową z kończyną chorą, poddaną działaniom fizjoterapeutycznym. Wiek chorych z uszkodzeniem stawu kolanowego zawierał się między 20. a 64. rokiem życia. Mediana wieku wynosiła 42 lata. Pacjenci pochodzili z obszarów miejskich i wiejskich powiatu staszowskiego. Reprezentowali różne zawody.

Wyniki: Zastosowana fizjoterapia wpłynęła na poprawę siły mięśniowej (mierzonej za pomocą stopni skali Lovetta) i zwiększenie zakresów ruchów (określanych w stopniach przy użyciu goniometru) kontuzjowanego stawu kolanowego. Oceniając efekty terapii, nie wykazano istotnej różnicy między grupami badanych poddanych kompleksowemu i częściowemu usprawnianiu.

Wnioski: Uzyskane wyniki usprawniania wykazały, że model fizjoterapii wzbogacony o ćwiczenia fizyczne pozwala na szybszy przyrost masy mięśniowej i wpływa na zwiększenie amplitudy zakresu ruchu w stawie kontuzjowanym. 


\section{Introduction}

Motor function of a knee is inseparably linked to its constant exploitation and exposure to multiple trauma. Traumatic damage to the knee joint often occurs as a result of the mechanism of sprains, dislocations or fractures. Likelihood of impairment of natural joint function increases in people actively participating in sport, especially professionally (e.g., skiing, hockey, skating, volleyball, basketball, football) and intensively training (e.g., dance) $[1,2]$. This does not mean, however, that the problem of damage to ligamentous-capsular and muscular-skeletal structures does not affect people conducting a peaceful lifestyle and preferring passive rest. The mechanism damaging a knee may also occur due to an incorrect setting of a foot on uneven ground, a fall or a locomotor accident.

In the construction of the knee joint (articulatio genus) there are many anatomical structures, each of which is characterized by a specific structure and functions. More important elements stabilizing the knee joint are ligaments: anterior cruciate ligament, posterior cruciate ligament, collateral lateral ligament called fibular, collateral medial ligament called tibial, and patellar ligament. "Stabilizers" play a huge role in the maintenance of joint efficiency, because they protect it from non-physiological movements. The correct range of knee motion is $120-150^{\circ}$ for flexion (the lower value refers to active knee flexion, and higher to passive) and $5-10^{\circ}$ tolerance for hyperextension [3]. According to Dziak, a "twist (distorsio) is a slight degree of strain of ligaments and joint capsules without interrupting their continuity. It is produced as a result of excessive amplitude of physiological or pathological motion" [4]. In the Anglo-Saxon medical literature there are two similar terms associated with traumatic injuries of the knee: strain (tearing) and sprain (twisting). The first term refers to an injury of the muscle-tendon unit, i.e. the belly of the muscle, its sinews and tendons; the second defines injury of a passively stabilizing mechanism, which includes ligaments and the joint capsule $[5,6]$. According to Kus, injury of the muscle-tendon unit (strain) can be divided into three types of damage depending on the severity: light first degree injury (delicate muscle strain), moderate second degree injury (muscle strain), and severe third degree injury (total disruption of the muscle). Kuś classified sprains of the knee according to severity of the damage. The resulting three-degree scale of sprains comprises: light, small sprain of the knee; moderate sprain; and serious, severe sprain of the knee. In the latter two cases, surgical treatment is recommended, preceded by imaging examination and diagnostic arthroscopy of the knee joint in order to eliminate the instability [7-9]. Light sprain requires medical treatment if the knee joint meets certain conditions for stability (no over-mobility in extension, medial-later- al laxity at flexion to $30^{\circ}$ less than $10^{\circ}$, a small effusion, joint stiffness subsiding before the day of injury). A popular model of early improvement is to use the RICE principle. The abbreviation comes from the first letters of the English words for therapeutic activities: $\mathrm{R}$ - rest; I - ice - cryotherapy, ice packs, cold gel packs; C - compression - pressure, tourniquet, stabilizing; E - elevation, alleviation. Later, after light sprain, mild, as well as severe, selected physical treatments are recommended using ultrasound, laser, liquid nitrogen monoxide/carbon dioxide or IR/UV, magnetic fields, galvanic currents, and interference with twoand four-pole currents $[10,11]$. A beneficial impact is observed with vibration or classic massage of quadriceps and the gastrocnemius muscle and lower limbs whirlpool. Kinesiotherapy is aimed at increasing the range of motion in the joint to the generally accepted physiological limit, strengthening the rectus femoris and gastrocnemius, and improving motor skills by pioneering impaired proprioception.

\section{Aim of the research}

The aim of this study was to determine the usefulness of kinesiotherapy in rehabilitation of the sprained knee joint by comparing the impact of complex knee physiotherapy (physical therapy associated with kinesiotherapy) with partial physiotherapy (only physiotherapy) in the process of shaping quadriceps muscle and triceps muscle of the calf and improvement of mobility of the knee joint.

\section{Material and methods}

The study involved 50 people with a history of knee sprains of 327 patients of the Rehabilitation Department of SPZZOZ in Staszów at 11 Listopad Street 78, who in a period from 1 December 2010 to 4 March 2011 attended rehabilitation. Patients were divided into 2 groups of 25 persons. They all agreed to participate in the study. Each patient was tested twice: before the start of rehabilitation and after (after 3 weeks). The first group consisted of persons using complex rehabilitation (15 women and 10 men), and the second consisted of persons willfully giving up the kinesiotherapeutic exercises ( 12 women and 13 men). The two treatment groups did not differ significantly by gender. The mean age of patients with damage to the knee was 42 years. The patients were from urban and rural areas of the Staszów region and were largely professionally active. The largest population of rehabilitation participants comprised women between 20 and 34 years of age (11 women), and the smallest comprised men in the same age group (5 men). Women more willingly than men chose therapeutic exercises in the rehabilitation process (Table 1). Physiotherapy was based on the use of: a scanning laser $(15 \times 10 \mathrm{~min})$, interference currents $(15 \times 20 \mathrm{~min})$, low frequency magnetic field 
Table 1. Information on age, sex and degree of involvement of the study subjects

\begin{tabular}{|c|c|c|c|c|c|c|c|c|c|c|}
\hline \multirow[t]{3}{*}{ Gender } & \multicolumn{6}{|c|}{ Age range [years] } & \multicolumn{4}{|c|}{ Rehabilitation } \\
\hline & \multicolumn{2}{|c|}{$20-34$} & \multicolumn{2}{|c|}{$35-49$} & \multicolumn{2}{|c|}{$50-64$} & \multicolumn{2}{|c|}{$F+K$} & \multicolumn{2}{|c|}{$\mathrm{F}$} \\
\hline & $n$ & $\%$ & $n$ & $\%$ & $n$ & $\%$ & $n$ & $\%$ & $n$ & $\%$ \\
\hline Women & 11 & 69 & 8 & 47 & 8 & 47 & 15 & 60 & 12 & 48 \\
\hline Men & 5 & 31 & 9 & 53 & 9 & 53 & 10 & 40 & 13 & 52 \\
\hline Total & \multicolumn{2}{|c|}{16} & \multicolumn{2}{|c|}{17} & \multicolumn{2}{|c|}{17} & \multicolumn{2}{|c|}{25} & \multicolumn{2}{|c|}{25} \\
\hline
\end{tabular}

$F+K$ - physiotherapy and kinesiotherapy, a complex rehabilitation model, $F$ - physiotherapy, partial rehabilitation model, $n$ - number, $\%$ - percentage of the population

Table 2. Occurrence of knee sprains compared to other disease entities

\begin{tabular}{|c|c|c|}
\hline \multirow[t]{2}{*}{ Diagnosis } & \multicolumn{2}{|c|}{$\begin{array}{l}\text { Number of people undergoing } \\
\text { rehabilitation }\end{array}$} \\
\hline & $n$ & $\%$ \\
\hline Knee joint sprain & 50 & 15 \\
\hline Other disease entity & 277 & 85 \\
\hline Total & \multicolumn{2}{|c|}{327} \\
\hline
\end{tabular}

Table 3. Number of injuries to the right and left knee joint in women and men

\begin{tabular}{|c|c|c|c|c|}
\hline \multirow[t]{3}{*}{ Gender } & \multicolumn{4}{|c|}{ Injured lower limb } \\
\hline & \multicolumn{2}{|c|}{ Right } & \multicolumn{2}{|c|}{ Left } \\
\hline & $n$ & $\%$ & $n$ & $\%$ \\
\hline Women & 18 & 64 & 9 & 41 \\
\hline Men & 10 & 36 & 13 & 59 \\
\hline Total & \multicolumn{2}{|c|}{28} & \multicolumn{2}{|c|}{22} \\
\hline$D_{f}$ value & \multicolumn{4}{|c|}{1} \\
\hline$\chi^{2}$ value (for $\left.p=0.05\right)$ & \multicolumn{4}{|c|}{$\begin{array}{l}\text { Empiric } 2.8 \\
\text { Critical } 3.84\end{array}$} \\
\hline$R_{c}$ & \multicolumn{4}{|c|}{0.23} \\
\hline Relationship strength & \multicolumn{4}{|c|}{ Weak } \\
\hline
\end{tabular}

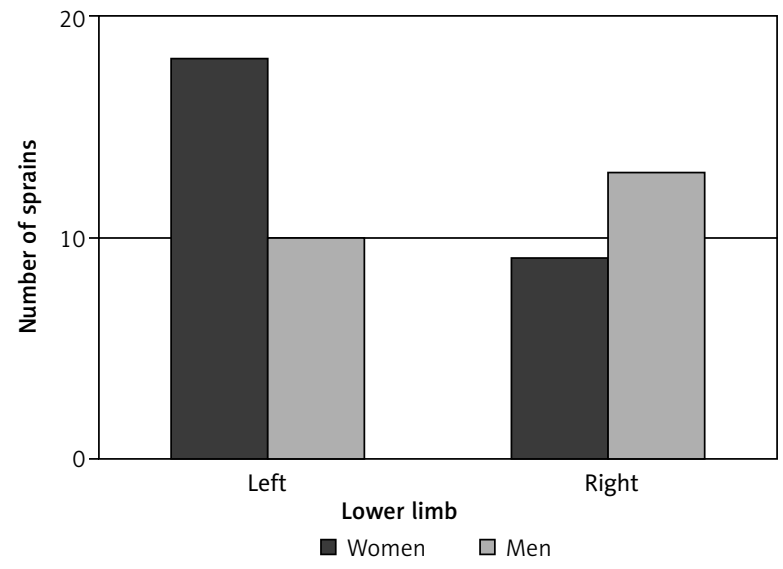

Figure 1. Location of knee joint sprain
$(15 \times 20 \mathrm{~min})$ and local cryotherapy $(15 \times 3 \mathrm{~min})$. The physical treatments were used by the two groups of patients. Kinesiotherapy consisted of knee extension exercises with submaximal load in a sitting position, riding a stationary bike, and individual training that improves the knee joint. Exercise time, the number of repetitions and load were adapted to the motor abilities of an individual patient. The exercise program was implemented by only one of the treatment groups. Patients independently and voluntarily chose the group. This paper studies performed statistical calculations, including the following calculations: chi-square $\left(\chi^{2}\right)$, coefficient of crosstabulation variation $\left(r_{c}\right)$ and the degrees of freedom $\left(d_{f}\right)$. Patients of Staszów district hospital were surveyed with a questionnaire of 22 points. Questions 1 to 7 and 15 to 18 were answered by the patients, giving their personal details, the intensity of pain and belonging to the group of people fully or partly engaged in the process of rehabilitation treatment. Other points of the survey were based on local orthopedic examination (measurement of muscle strength, range of motion of the knee, thigh and lower leg circumference). Measuring instruments such as a goniometer and tailoring meter were used.

\section{Results}

In the period from 1 December 2010 to 4 March 2011, 327 patients benefited from rehabilitation in the Daily Department of SPZZOZ in Staszów, including those with traumatic knee joint - there were 50 sprains (15\%), and 277 other diseases (85\%) (Table 2). More often the right knee joint was injured ( 28 patients, 56\%) as compared with the left (22 patients, $44 \%$ ) (Table 3). In the studied women, right knee sprain $(18,67 \%)$ occurred twice as often as the left $(9,33 \%)$. Men more often declared left knee injury $(13,57 \%)$ than the right $(10,43 \%)$ (Table 3, Figure 1). Between gender and the side of the knee injury the correlation is low, the relation clear, but small $\left(\chi^{2}=2.8\right.$; $\left.r_{c} \approx 0.23 ; d_{f}=1\right)$. The strength of the quadriceps muscle and gastrocnemius muscle in healthy leg according to the Lovett scale was usually 5 , which was the maximum. Before physical treatments quadriceps strength 
Table 4. Strength of selected muscles according to Lovett scale in patients participating in partial physiotherapy of knee joint

\begin{tabular}{|c|c|c|c|c|c|c|c|c|c|c|c|c|}
\hline \multirow[t]{4}{*}{ Knee joint } & \multicolumn{12}{|c|}{ Tested muscle } \\
\hline & \multicolumn{6}{|c|}{ Quadriceps (straight head) } & \multicolumn{6}{|c|}{ Gastrocnemius } \\
\hline & \multicolumn{2}{|c|}{ Strength 3} & \multicolumn{2}{|c|}{ Strength 4} & \multicolumn{2}{|c|}{ Strength 5} & \multicolumn{2}{|c|}{ Strength 3} & \multicolumn{2}{|c|}{ Strength 4} & \multicolumn{2}{|c|}{ Strength 5} \\
\hline & $n$ & $\%$ & $n$ & $\%$ & $n$ & $\%$ & $n$ & $\%$ & $n$ & $\%$ & $n$ & $\%$ \\
\hline Healthy & 0 & 0 & 3 & 12 & 22 & 88 & 0 & 0 & 1 & 4 & 24 & 96 \\
\hline $\begin{array}{l}\text { Injured before partial } \\
\text { rehabilitation }\end{array}$ & 1 & 4 & 15 & 60 & 9 & 36 & 0 & 0 & 5 & 20 & 20 & 80 \\
\hline $\begin{array}{l}\text { Injured after partial } \\
\text { rehabilitation }\end{array}$ & 0 & 0 & 10 & 40 & 15 & 60 & 0 & 0 & 0 & 0 & 25 & 100 \\
\hline$D_{f}$ value & & & & & \multicolumn{8}{|c|}{2} \\
\hline$\chi^{2}$ value (for $\left.p=0.05\right)$ & & & & & \multicolumn{8}{|c|}{$\begin{array}{l}\text { Empiric } 3.1 \\
\text { Critical } 5.99\end{array}$} \\
\hline$R_{c}$ & & & & & \multicolumn{8}{|c|}{0.24} \\
\hline Relationship strength & & & & & \multicolumn{8}{|c|}{ Weak } \\
\hline
\end{tabular}

was 3 by Lovett scale (1 person, $4 \%$ ), 4 by the same scale (15 persons, $36 \%)$ and 5 (9 persons, $60 \%)$. The strength of the gastrocnemius muscle was usually the maximum (20 persons, $80 \%$ ) and slightly lower - 4 (5 persons, 20\%). After 3-week partial (physical) physiotherapy the strength of the quadriceps muscle showed 4 (10 patients, $40 \%$ ) by the adopted test scale and 5 (15 persons, 60\%). The gastrocnemius muscle in patients in general represented the maximum muscle strength (100\%) (Table 4, Figure 2). The relationship between partial improvement of the knee joint and strengthening the quadriceps and gastrocnemius is clear, but small, and the correlation is low $\left(\chi^{2}=3.1\right.$; $r_{c} \approx 0.24 ; d_{f}=2$ ).

The muscle strength of the healthy lower limb on the Lovett scale was usually 5 (on average 88\%). Before complex physiotherapy, quadriceps muscle strength was: 3 on the Lovett scale $(5,20 \%), 4$ on the same scale (10 persons, 40\%) and 5 (10 persons, 40\%). Gastrocnemius muscle strength was usually maximum (19 persons, $76 \%$ ), slightly lower - 4 (5 persons, $20 \%$ ) and 3 (1 person, 4\%). After 3-week complex rehabilitation the muscle strength of the quadriceps showed 4 (7 persons, 28\%) according to the adopted test scale and 5 (18 persons, $72 \%)$. The gastrocnemius muscle in the majority of patients achieved the strength of 5 (22 patients, 88\%) and 4 (3 persons, 12\%) (Table 5, Figure 3). The relationship between the rehabilitation of the knee joint with physiotherapy associated with kinesiotherapy and strengthening the quadriceps muscle is clear, although small, and the correlation is low $\left(\chi^{2}=5.3 ; r_{c} \approx 0.31 ; d_{f}=2\right)$. In the case of the gastrocnemius muscle the relationship is presented as almost not significant, and the correlation is poor $\left(\chi^{2}=1.3\right.$; $r_{c} \approx 0.17 ; d_{f}=2$ ).

Increase in muscle mass in patients was measured by reduction of each muscle circumference measure-

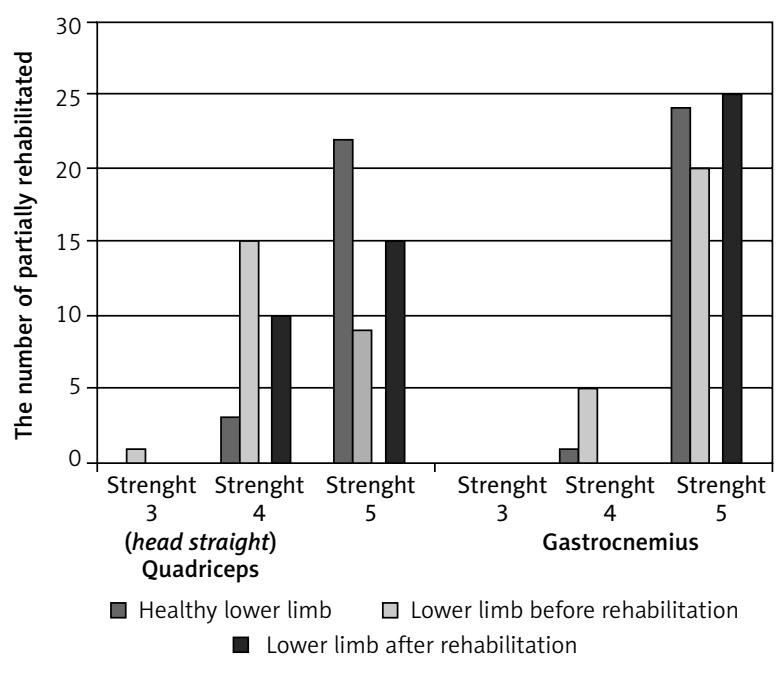

Figure 2. Muscle strength in patients after partial rehabilitation of knee joint

ment after the rehabilitation by the measurement made before the therapeutic improvement of the injured limb. Classification of measurements indicated no increase in muscle in $1 / 3$ thigh further in 15 patients $(60 \%), 1 / 3$ thigh proximal in 13 patients $(52 \%)$, and in lower leg in 18 patients (72\%) partially rehabilitated. A $1-\mathrm{cm}$ increase was observed in 8 patients (32\%) in $1 / 3$ thigh further, in 9 patients (36\%) in $1 / 3$ thigh proximal, and in 5 patients (8\%) in the lower leg. A maximum of $2 \mathrm{~cm}$ increased the circumstances of 2 people $(8 \%)$ in $1 / 3$ thigh further, 2 people $(8 \%)$ in the lower leg and 3 people (12\%) in $1 / 3$ thigh proximal (Table 6, Figure 4).

The difference in the measurements of circumstances of the studied subjects indicated no increase in muscle in $1 / 3$ proximal thigh in 2 patients $(8 \%)$, and in the lower leg in 7 patients (28\%) completely rehabil- 
Table 5. Strength of selected muscles according to Lovett scale in patients undergoing complex physiotherapy of knee joint

\begin{tabular}{|c|c|c|c|c|c|c|c|c|c|c|c|c|}
\hline \multirow[t]{4}{*}{ Knee joint } & \multicolumn{12}{|c|}{ Tested muscle } \\
\hline & \multicolumn{6}{|c|}{ Quadriceps (head straight) } & \multicolumn{6}{|c|}{ Gastrocnemius } \\
\hline & \multicolumn{2}{|c|}{ Strength 3} & \multicolumn{2}{|c|}{ Strength 4} & \multicolumn{2}{|c|}{ Strength 5} & \multicolumn{2}{|c|}{ Strength 3} & \multicolumn{2}{|c|}{ Strength 4} & \multicolumn{2}{|c|}{ Strength 5} \\
\hline & $n$ & $\%$ & $n$ & $\%$ & $n$ & $\%$ & $n$ & $\%$ & $n$ & $\%$ & $n$ & $\%$ \\
\hline Healthy & 0 & 0 & 5 & 20 & 20 & 80 & 0 & 0 & 1 & 4 & 24 & 96 \\
\hline $\begin{array}{l}\text { Injured before complex } \\
\text { rehabilitation }\end{array}$ & 5 & 20 & 10 & 40 & 10 & 40 & 1 & 4 & 5 & 20 & 19 & 76 \\
\hline $\begin{array}{l}\text { Injured after complex } \\
\text { rehabilitation }\end{array}$ & 0 & 0 & 7 & 28 & 18 & 72 & 0 & 0 & 3 & 12 & 22 & 88 \\
\hline$D_{f}$ value & \multicolumn{6}{|c|}{2} & \multicolumn{6}{|c|}{2} \\
\hline$\chi^{2}$ value (for $\left.p=0.05\right)$ & \multicolumn{6}{|c|}{$\begin{array}{l}\text { Empiric } 5.3 \\
\text { Critical } 5.99\end{array}$} & \multicolumn{6}{|c|}{$\begin{array}{l}\text { Empiric } 1.3 \\
\text { Critical } 5.99\end{array}$} \\
\hline$R_{c}$ & \multicolumn{6}{|c|}{0.31} & \multicolumn{6}{|c|}{0.17} \\
\hline Relationship strength & \multicolumn{6}{|c|}{ Average } & \multicolumn{6}{|c|}{ Weak } \\
\hline
\end{tabular}

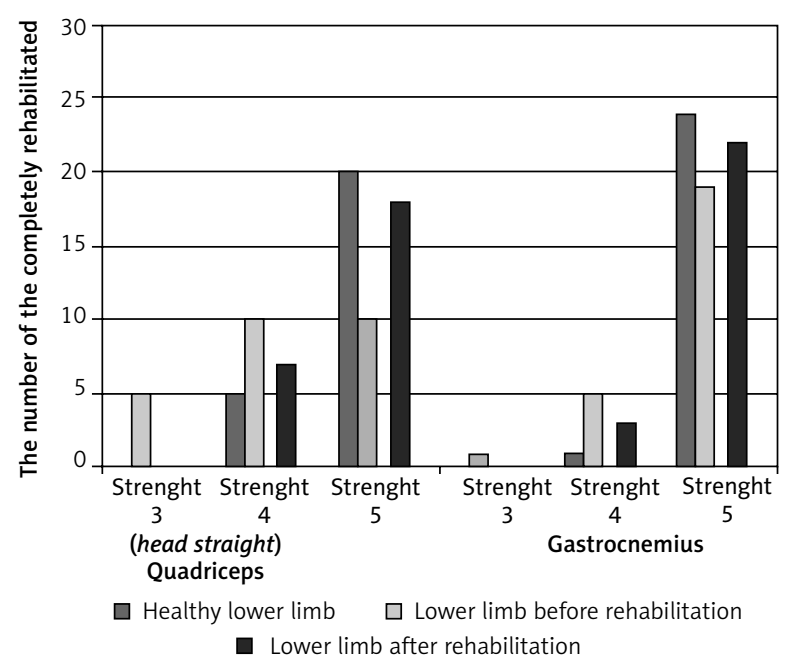

Figure 3. Muscle strength in patients after complex rehabilitation of knee joint

itated. One-centimeter growth was observed in 16 patients (64\%) in 1/3 thigh further, in 13 patients $(52 \%)$ in $(1 / 3$ thigh proximal), and in 15 patients $(60 \%)$ in the lower leg. Two-cm growth of circumference occurred in seven patients (28\%) in $1 / 3$ thigh further and in one person $(4 \%)$ in (1/3 proximal thigh). Three-centimeter muscle growth was observed only on the thigh: in $1 / 3$ further thigh in 2 patients (4\%) and in $1 / 3$ proximal thigh in 1 (4\%) (Table 7, Figure 5).

Increase in the range of motion in the knee joint after injury was calculated by comparing the range of motion before and after therapeutic improvement. Extension of the partly rehabilitated knee in 6 cases $(24 \%)$ did not change after rehabilitation. In 16 patients $(64 \%)$ of the unit there was an increase in the range of motion by $5^{\circ}$ and in $3(12 \%)$ by $10^{\circ}$. The range of flexion in the knee joint did not increase in 6 patients $(24 \%)$ partially rehabilitated, in 11 patients $(44 \%)$ increased by $5^{\circ}$ and in 8 patients $(32 \%)$ by $10^{\circ}$. None of the patients reached a 15-degree improvement of the range of motion in the knee joint (Table 8, Figure 6). Extension of the knee completely rehabilitated in 4 cases $(16 \%)$ did not change after rehabilitation. In 17 patients $(68 \%)$ of the unit there was an increase in the range of motion of extension by $5^{\circ}$, in $2(8 \%)$ by $10^{\circ}$, and in $2(8 \%)$ by $15^{\circ}$ or more. The range of flexion of the knee did not increase in 5 patients $(20 \%)$ completely rehabilitated, in 5 patients $(20 \%)$ increased by $5^{\circ}$, in 12 patients $(48 \%)$ by $10^{\circ}$ and in 3 patients (12\%) by $15^{\circ}$ or more (Table 8 , Figure 7).

The relationship between the applied rehabilitation and the increase in the range of active motion of

Table 6. Muscle growth in the diseased lower limb after partial rehabilitation

\begin{tabular}{|c|c|c|c|c|c|c|c|c|}
\hline \multirow[t]{3}{*}{ Location of measurement } & \multicolumn{8}{|c|}{ Muscle growth } \\
\hline & \multicolumn{2}{|c|}{ Lack } & \multicolumn{2}{|c|}{$1 \mathrm{~cm}$} & \multicolumn{2}{|c|}{$2 \mathrm{~cm}$} & \multicolumn{2}{|c|}{$3 \mathrm{~cm}$} \\
\hline & $n$ & $\%$ & $n$ & $\%$ & $n$ & $\%$ & $n$ & $\%$ \\
\hline Thigh $10 \mathrm{~cm}$ above base of patella & 15 & 60 & 8 & 32 & 2 & 8 & 0 & 0 \\
\hline Thigh $20 \mathrm{~cm}$ above base of patella & 13 & 52 & 9 & 36 & 3 & 12 & 0 & 0 \\
\hline Lower leg $15 \mathrm{~cm}$ below top of patella & 18 & 72 & 5 & 20 & 2 & 8 & 0 & 0 \\
\hline
\end{tabular}




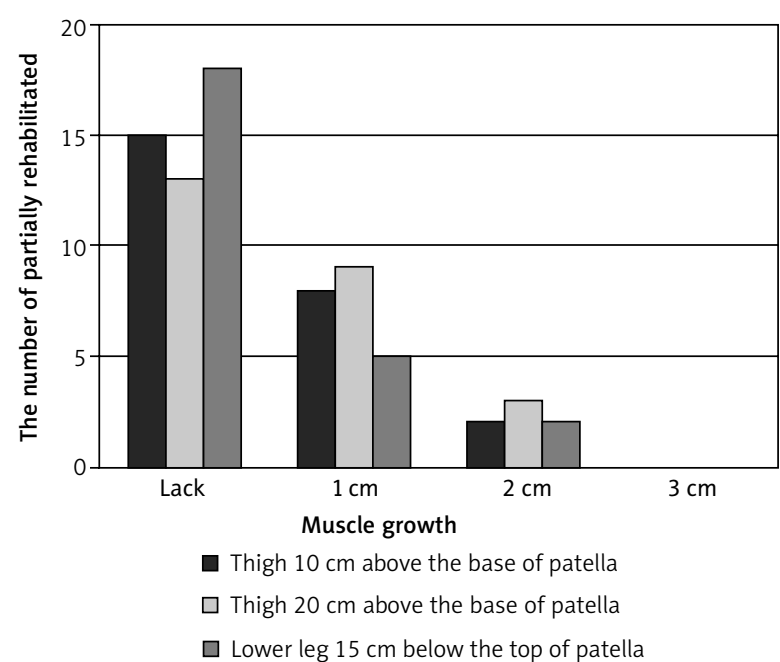

Figure 4. Muscle growth in the injured lower limb in patients after partial rehabilitation

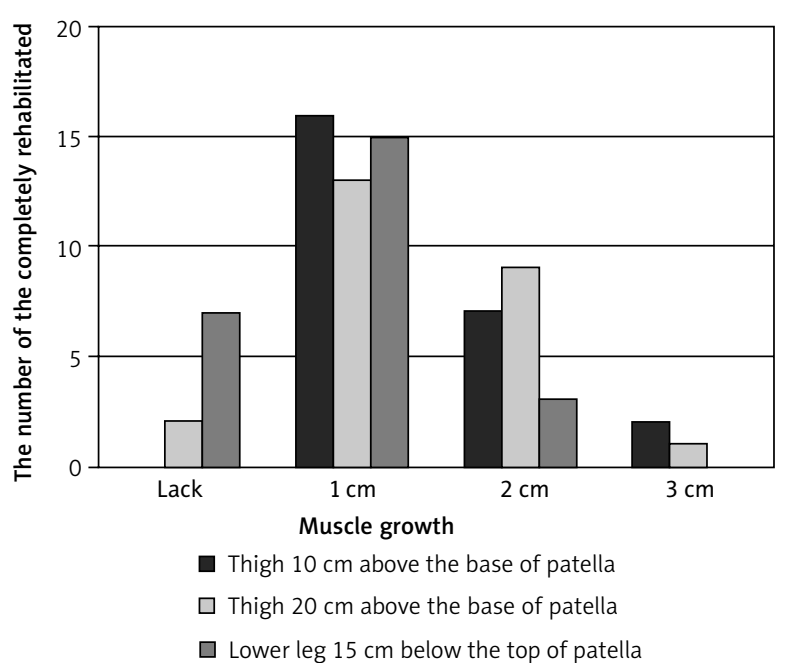

Figure 5. Muscle growth in the injured lower limb in patients after complex rehabilitation

Table 7. Muscle growth in the injured lower limb after complex rehabilitation

\begin{tabular}{|c|c|c|c|c|c|c|c|c|}
\hline \multirow[t]{3}{*}{ Location of measurement } & \multicolumn{8}{|c|}{ Muscle growth } \\
\hline & \multicolumn{2}{|c|}{ Lack } & \multicolumn{2}{|c|}{$1 \mathrm{~cm}$} & \multicolumn{2}{|c|}{$2 \mathrm{~cm}$} & \multicolumn{2}{|c|}{$3 \mathrm{~cm}$} \\
\hline & $n$ & $\%$ & $n$ & $\%$ & $n$ & $\%$ & $n$ & $\%$ \\
\hline Thigh $10 \mathrm{~cm}$ above base of patella & 0 & 0 & 16 & 64 & 7 & 28 & 2 & 8 \\
\hline Thigh $20 \mathrm{~cm}$ above base of patella & 2 & 8 & 13 & 52 & 9 & 36 & 1 & 4 \\
\hline Lower leg $15 \mathrm{~cm}$ below top of patella & 7 & 28 & 15 & 60 & 3 & 12 & 0 & 0 \\
\hline
\end{tabular}

Table 8. Increase in the range of motion in knee joint after partial and complex rehabilitation

\begin{tabular}{|c|c|c|c|c|c|c|c|c|c|c|c|c|c|c|c|}
\hline \multirow[t]{4}{*}{ Motion } & \multicolumn{15}{|c|}{ Increase in the range of motion } \\
\hline & \multicolumn{8}{|c|}{$F$} & \multicolumn{7}{|c|}{$F+K$} \\
\hline & \multicolumn{2}{|c|}{ Lack } & \multicolumn{2}{|c|}{ By $5^{\circ}$} & \multicolumn{2}{|c|}{ By $10^{\circ}$} & \multicolumn{2}{|c|}{$\begin{array}{l}\text { By } 15^{\circ} \\
\text { and more }\end{array}$} & \multicolumn{2}{|c|}{ Lack } & \multicolumn{2}{|c|}{ By $5^{\circ}$} & By $10^{\circ}$ & \multicolumn{2}{|c|}{$\begin{array}{c}\text { By } 15^{\circ} \\
\text { and more }\end{array}$} \\
\hline & $n$ & $\%$ & $n$ & $\%$ & $n$ & $\%$ & $n$ & $\%$ & $n$ & $\%$ & $n$ & $\%$ & $n \%$ & $n$ & $\%$ \\
\hline Extension & 6 & 24 & 16 & 64 & 3 & 12 & 0 & 0 & 4 & 20 & 17 & 68 & 8 & 2 & 8 \\
\hline Flexion & 6 & 24 & 11 & 44 & 8 & 32 & 0 & 0 & 5 & 20 & 5 & 20 & 1248 & 3 & 12 \\
\hline$D_{f}$ value & \multicolumn{8}{|c|}{ Extension } & \multicolumn{7}{|c|}{ Flexion } \\
\hline $\begin{array}{l}\chi^{2} \text { value } \\
(\text { for } p=0.05)\end{array}$ & \multicolumn{8}{|c|}{$\begin{array}{l}\text { Empiric } 1.6 \\
\text { Critical } 7.81\end{array}$} & \multicolumn{7}{|c|}{$\begin{array}{l}\text { Empiric } 4.7 \\
\text { Critical } 7.81\end{array}$} \\
\hline$R_{c}$ & \multicolumn{8}{|c|}{0.17} & \multicolumn{7}{|c|}{0.3} \\
\hline Relation strength & \multicolumn{8}{|c|}{ Weak } & \multicolumn{7}{|c|}{ Average } \\
\hline
\end{tabular}

extension in the knee joint is almost insignificant and the correlation is weak $\left(\chi^{2}=1.6 ; r_{c} \approx 0.17 ; d_{f}=3\right)$. The relationship between the applied rehabilitation and the increase in the range of active flexion in the injured knee joint is clear, but small, and the correlation is low $\left(\chi^{2}=4.7 ; r_{c} \approx 0.3 ; d_{f}=3\right)$.

\section{Discussion}

The study showed that many people rehabilitated in a state hospital in Staszów are suffering from impaired function of the knee joint due to sprain (15\%). The numbers of men and women, and rural and ur- 


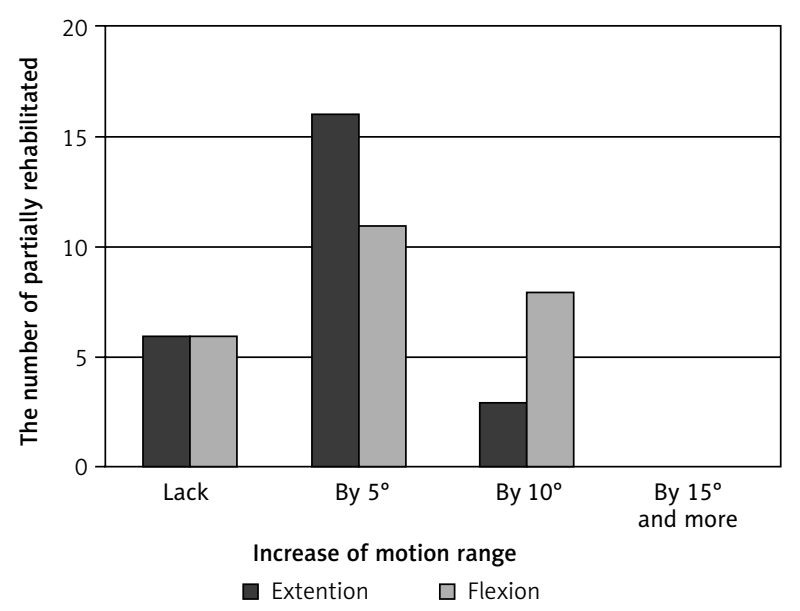

Figure 6. Increase in motion range in knee joint after partial rehabilitation

ban populations, were well balanced. But women from rural areas were more often rehabilitated than those from urban areas, while for men the opposite was true - a larger group were men from a town. Literature attributes knee injuries to young people $[8,10]$. The groups of 50 people undergoing observation did not show such a trend. The number of patients in all age groups was very similar. Patients performing daily physical labor made up more than one third of the group rehabilitated, which indicates the importance of movement in the formation of knee sprains. In general the study subjects were more prone to right knee sprains. This situation coincides with increased right knee injury rates in studies on the effectiveness of rehabilitation after arthroscopic reconstruction of the anterior cruciate ligament $[12,13]$. Knee injury most frequently causes damage to the anterior cruciate ligament (ACL), nearly $80 \%$ of cases. Among women also the right leg underwent more damage as opposed to the population of men who usually had the left leg injured. Complex treatment (physiotherapy and kinesiotherapy) was usually chosen by women and middle-aged people. Young and elderly people avoided exercise, explaining that they did not have enough time or they doubted the effectiveness of the treatment. Physiotherapy was by almost all patients recognized as a "silver bullet" in the treatment of weakened knee joint function. After partial rehabilitation quadriceps strength increased slightly by approximately $0.3^{\circ}$ on the Lovett scale, while after complex rehabilitation the growth was more than $0.5^{\circ}$. Both partial and complex rehabilitation strengthened the triceps muscle by $0.2^{\circ}$ on the Lovett scale. Differences in strengthening the significant muscles of the injured lower limb between the particular models are small, and the results are insignificant or slightly significant statistically. In the group of patients using only physical treatments the range of extension in the knee joint increased on av-

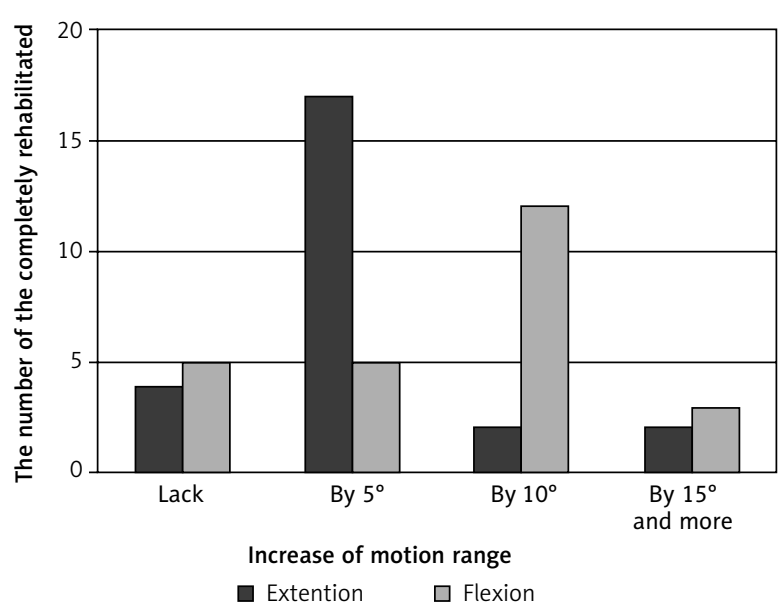

Figure 7. Increase in motion range in knee joint after complex rehabilitation

erage by $4.4^{\circ}$, and was smaller by $1^{\circ}$ than the average range of extension after rehabilitation enriched with medical exercise. The range of knee flexion increased on average by $5.4^{\circ}$ in the group treated with partial rehabilitation and by $2.2^{\circ}$ more $\left(7.6^{\circ}\right)$ in the compared group. Differences in the two groups are statistically insignificant. Kinesiotherapy has no significant effect on the growth of muscle strength, circumstances of the injured limb and the range of motion in the knee joint [14].

\section{Conclusions}

Women show a greater involvement in the process of rehabilitation and often take advantage of all the available methods and means. The physical rehabilitation after an episode of knee sprain enriched with kinesiotherapy helps to achieve better results of rehabilitation. Physical exercise can slightly increase the range of flexion of the knee and strengthen the quadriceps muscle.

\section{References}

1. Dick R, Ferrara MS, Angel J. Descriptive epidemiology of collegiate men's football injuries. J Athl Train 2007; 2: 221233.

2. Rishiray M, Lloyd-Smith R, Lorenz T. University men's ice hockey: rates and risk of injuries over 6-years. J Sports Med Phys Fitness 2009; 2: 159-166.

3. Reicher M, Bochenek A. Anatomia człowieka. Tom I. Anatomia ogólna. Kości, stawy i więzadła. Mięśnie. PZWL, Warszawa 2007.

4. Żuk T, Dziak A, Gusta A. Podstawy ortopedii i traumatologii. PZWL, Warszawa 1983.

5. Marchewczyk J. Urazy jednostki mięśniowo-ścięgnistej (strain) oraz urazy aparatu biernie stabilizującego (sprain) w obrębie stawu kolanowego. Materiały II Sympozjum Obrażeń Sportowych Kolana, Suwałki 1980.

6. Kuś WM. Urazowe uszkodzenia kolana. PZWL, Warszawa 1984. 
7. Ritter R, Axe M, Godges J et al. Knee stability and movement coordination impairments: knee ligament sprain. JOSPT 2010; 40: 1-37.

8. Sekcja Chirurgii Kolana i Traumatologii Sportowej PTOiT. Chirurgia kolana, artroskopia, traumatologia sportowa. Sport \& Med, Katowice 2007.

9. Wąsowski M, Płończak M. Wyniki leczenia niestabilności przedniej stawów kolanowych z zastosowaniem endoprotezy Leeds-Keio. Postępy Nauk Medycznych 2010; 2 128-132

10. Dziak A, Tayara S. Urazy i uszkodzenia w sporcie. Kasper, Kraków 2009.

11. Bojek W. Krioterapia - uwagi ogólne. Balneol Pol 2006; 1: 64-67.

12. Wright RW, Fetzer GB. Bracing after ACL reconstruction - a systematic review. Clin Orthop Relat Res 2007; 45: 162 168

13. Wilk M, Trąbka R, Tomaszewski W. Wstępne wyniki zastosowania protokołu rehabilitacyjnego we wczesnym okresie u pacjentów po artroskopowej przezportalowej jedno i dwupęczkowej rekonstrukcji więzadła krzyżowego przedniego z użyciem ścięgien mięśni półścięgnistego i smukłego. Fizjoter Pol 2009; 9: 97-103.

14. Polak A, Feige A, Grymel-Kulesza E et al. Badanie skuteczności wybranych środków fizykalnych u chorych we wczesnym okresie po operacyjnym leczeniu więzadła krzyżowego przedniego. Fizjoter Pol 2010; 10: 12-24

\section{Address for correspondence:}

Jacek Wilczyński MD

Institute of Physiotherapy

Jan Kochanowski University

ul. Żeromskiego 5, 25-369 Kielce, Poland

Phone: +48 603703926

E-mail: jwilczynski@onet.pl 